\title{
A Schematic Discoursal Study of Chinese Football Players' Commercial Transfer News
}

\author{
Wenhui Yang ${ }^{1}$, Junpeng Zhao ${ }^{2}$, Kaiyue Zhen ${ }^{3}$ \\ ${ }^{1}$ International College, Guangdong University of Foreign Studies, Guangzhou, Guangdong, 510420, P. R. China \\ ${ }^{2}$ School of English for International Business, Guangdong University of Foreign Studies, Guangzhou, Guangdong, \\ 510420, P. R. China \\ ${ }^{3}$ Sauder Business School, University of British Columbia, Vancouver, Canada \\ Correspondence: Kaiyue Zhen, Sauder Business School, University of British Columbia, Vancouver, British Columbia, \\ V6T 1Z4, Canada.
}

Received: July 22, 2018

Accepted: August 22, $2018 \quad$ Online Published: August 28, 2018

doi:10.11114/smc.v6i2.3575

URL: https://doi.org/10.11114/smc.v6i2.3575

\begin{abstract}
This cognitive discoursal study explores human cognitive mechanisms by analyzing Football Players' Commercial Transfer News (FPCTN) through adopting Gibbs' (2010) embodied view of image schemas in language use and their interpretations in Chinese sports contexts, based on the database of 36 pieces of news reports collected from authoritative sports websites. The results demonstrate that FPCTN writers actively construct their meanings and perspectives by applying various metaphysical and metaphysicalized forms of image schemas, which are grounded on our knowledge and daily bodily experience. Discourse consumers, on the other hand, unconsciously engage themselves in imaginative simulation processes, which are fundamentally embodied in their past and present bodily experiences, to facilitate their understanding of linguistic information and writers' intentions, which predicates the process of public general cognition construction and frame, meanwhile, constituting the mechanism of a news reader's passionate identification with and attachment to a potential commodity in his/her social and entertainment life.
\end{abstract}

Keywords: FPCTN, image schema, formulaic, metaphysical(ized) expressions, sports discourse

\section{Introduction}

Sports media nexus plays a significant role in the information of the trading of players, field of sport and its discourses and practices: it has effectively redefined how spectators see and experience games, and indeed what we understand by the notion of spectatorship (Schirato, 2013). Sports news is characterized by information about latest events in the field of sports, including sports training and immediate competitive form of athletes, pre-match predictions, instant real-time reports, sporting competition results, after-match evaluation of specific players' performance and coaches' strategic planning, entertaining side stories, eye-catching transfer rumors and news, the establishment and revision of sports regulations and so on. It is an excellent channel for transmitting humanistic spirit, because sports coverage not only disseminates information concerning latest sports events, but also guides news readers to witness human's challenges, conquests, and transcending of themselves as well as the pursuit of perfection. Just as van Dijk (1997) remarks, the main stream of news reporting is about politics, economy and military while news reports on sports and other subjects only account for a small fraction, which attract insufficient academic studies. Although the number of studies on sports news discourse is constantly on the rise currently, few academic efforts have been devoted to the combination of cognitive linguistics and sports news discourse, especially in terms of sports players' commercial transfer news and the perspectives of cognitive schema.

In this paper, the authors will analyze Chinese sports discourse on Football Players' Commercial Transfer News (FPCTN) to figure out: "How FPCTN discourse writers frame their cognition through image schemata? And how FPCTN discourse writers weave their intentions and ideas into their passages to associate to and frame readers' cognition of the sports world?" Through this research, the authors wish to identify the news readers' recreation of simulation processes based on given linguistic cues and recalled individual experiences to decipher linguistic codes and facilitate their understanding of writers' messages, and different parties' and stake-holders' projections of their cognitions on various football-players-transaction-related occasions, maintaining the integrity of their interests in sports business world. 


\section{Studies of Sports News Discourses and Image Schema}

\subsection{Sports News Discourse}

Sports news is a unique news category, which is characterized by information about the latest events in the field of sports, including sports training and immediate competitive form of athletes, pre-match predictions, instant real-time reports, sporting competition results, after-match evaluation of specific players' performance and coaches' strategic planning, entertaining side stories, eye-catching transfer rumors and news, the establishment and revise of sports regulations and so on. There are quite a few discourse analyses of sports news emerging over the years from the perspectives of pragmatics, communication, interactional sociolinguistics and ethnographic studies (Dana, Erin \& Anita, 2011; Li \& Li, 2010; Schirato, 2013; Shen, 2010; Yoshiaki \& Yasuo, 2000; Wang, 2013). Among them, Schirato (2013) gives an account of the cultural field of sport by way of a consideration of the discourses (both historical and contemporary) that are specific to, and play a significant role within and across, that sport. He argues that "......the events, sites, contests, organizations, rules, infrastructure, technologies and bodies that constitute the context, materiality and the visual and emotional realities of sport, from an impromptu kick-about in a backstreet to the media-intensive coverage of a World Cup or Olympic Final, are experienced and rendered explicable and meaningful by way of the discursive frames applied to them" (Schirato, 2013:1). Similar to Foucault's (1972) statements on discourses that they are not just collection of signs, but practices that systematically form the objects of which they speak, Frow (2006) further argues that discourses carry out an action, they are systematic and formative to build a weight of meaning around the categories of the world. Discourses are performative structures that shape the world in the very process of putting it in to speech. With the development of discourse studies, there are multiple approaches to sports news discourses, many disciplines have been covered with fruitful and abundant findings in last decade (Aitchison, 2007; Carrington \& McDonald, 2009; McGannon, 2016; Smith \& Sparkes, 2016; Tomlinson, 2007). These researches explore the different methods used to collect and analyze sports discourses, offering rationales for studies, and also introducing important contemporary debates with new research methods, concepts, and scenarios, such as sensory research, digital research, visual methods, and how qualitative research can generate impact.

From a cognitive perspective, $\mathrm{Li}$ and $\mathrm{Li}$ (2010) conduct an interesting research into the phenomenon of anaphora and NP anaphora in Chinese and English sports news discourses, decipher the cognitive mechanism of NP anaphora construction, and probe into the functions of metaphor and metonymy in such discourses. Cross-culturally, through a contrastive study of Chinese and English sports news discourses, Liu and Liu (2005) have analyzed metaphors and their functions from the perspective of cognitive linguistics, and summarized three major functions of metaphors in sports news discourse: textual function, aesthetic function and social function. They argued that the metaphorical expression "SPORTS CONTESTS ARE WARS" exhibits cross-cultural similarity and universality; moreover, it will potentially exert a negative influence on social function and lead to sports enthusiasts' misunderstanding of sports contest and neglect of the essence of sports: promoting cross-cultural communication and furthering the cause of sports. As the authors mentioned, the language that sports news reports employ reveals the writers' personal standpoints and hence sports enthusiasts are highly likely to be influenced unconsciously, which makes it important to analyze sports news from cognitive perspectives, to figure out how to acquire news writers' standpoints and intentions, and how general sports news exerts influences on sports news readers' perception and cognition.

\subsection{Image Schema}

Studies in cognitive linguistics have shown that much of ordinary human cognition is not represented in terms of propositional and sentential information but is grounded in and structured by various patterns of our perceptual interactions, bodily actions, and manipulations of objects (Johnson, 1987; Lakoff, 1987; 1990). These patterns are experiential gestalts and called "image schemata". Image schemata are neither images nor schemata in the familiar senses of each term as used in philosophy, cognitive psychology, or anthropology. According to Johnson (1987:29), an image schema is "a recurring, dynamic pattern of our perceptual interactions and motor programs that gives coherence and structure to our experience". He points out that these patterns "emerge as meaningful structures for us chiefly at the level of our bodily movements through space, our manipulations of objects, and our perceptual interactions". Image schemata are pre-conceptual abstract knowledge structures based on recurrent patterns of experience. Similarly, Lakoff (1987:267) defines image schema as: "relatively simple structures that constantly recur in our everyday bodily experience: CONTAINERS, PATH, LINKS, FORCES, BALANCE, and in various orientations and relations: UP-DOWN, FRONT-BACK, PART-WHOLE, CENTER-PERIPHERY, etc.'He argues that the image-schematic structure is treated as one of the two pre-conceptual structures in our bodily experiences that give rise to conceptual structure, the other one being basic-level categories which are characterized by gestalt perception, mental imagery and movements. A gestalt structure is a structure whose elements do not all exist dependent of the whole or whose overall meaning is not predictable from the meanings of its parts and the way those parts are put together. 
Different from Lakoff and Johnson's (1980) traditional perspectives, Gibbs (2010) considers, in great details, the matter of whether image schemas are enduring mental representations, or better understood as temporary linkages between sensory experience and short-lived conceptualizations of both concrete events and abstract ideas. He contends that image schemas are not "representational structures" that provide the causal basis for thought and language, but are fleeting entities that are part of the embodied simulations used in online thought, including abstract reasoning. He proposes that image-schematic reasoning is always being recreated by the body as people are continuously engaged in sensorimotor behaviors associated with BALANCE, RESISTENCE, SOURCE-PATH-GOAL, CONTAINMENT, etc. He highlights the phenomenology of the human body in action, insisting that bodily schemas do not just produce image schemas, but that image schemas including more static ones, are continually tied to embodied action and simulations of experience. For example, body schema is a concept applied in several disciplines, including psychology, neuroscience, philosophy, sports medicine, and robotics. Body schemas underlie how the body actively integrates its posture and position in the environment (Gallagher \& Cole, 1995). Body schemas enable us to walk swiftly and avoid running into or tripping over things, to follow and locate objects, to perceive shape, distance, duration, and to catch a ball accurately.

Image-schematic reasoning may also be contingent on the embodied simulations created in different situations. Gibbs (2010) claims that image schemas are embodied simulations which are grounded upon the conception of an actual "simulator". A simulator provides something closely approximate to what it actually feels like in a full-bodied manner to, say, fly an aircraft in a flight simulator where one feels all the movements associated with flying a real plane. Image schemas, from this perspective, are simulators of actions that are based on real-life actions and potential actions that a person may engage in. The simulators can provide kinesthetic feelings that are the results of full-bodied experiences which have textures and a felt-sense of three-dimensional depth, as contradictory to Johnson's (1987) concerns about image schemas as "fleshless skeletons". For instance, when someone utters "nothing down, nothing up", he/she refers to both the presence of sadness and the prospect of happiness in human daily life, indicating the earthly inevitability of adverse situations or even hitting rock bottom, as well as the possible change of situations over the course of a lifetime. This remark is understood metaphorically in terms of SCALE/UP-DOWN Schema and how the terrible situation can sometimes render one devastated and desperate. We do not merely process this sort of utterance in an abstract manner, but implicitly understand it by imagining what it feels like to be involved in such circumstances, even by recalling personal experiences in the course of which we have similar feelings and empathy. Looking at image schema as "simulations of bodily action" properly acknowledges how image schemas are "experiential gestalts" or "as-if body" loops (Damasio, 1999; 2003) that are actively created on-the-fly in the course of different cognitive activity, but are not encoded "structures in the head" that is passively activated as part of unconscious linguistic understanding processes.

Gibbs' (2006) argument has been articulately explicated that: image schemas are created on-the-fly as part of people's ongoing simulations of actions when they engage in cognitive tasks, such as understanding language. Image schemas are not divorced from their bodily origins, despite their emergence from recurring patterns of bodily experience, nor are they structured as pre-stored entities in long-term memory. Instead, image schemas are emergent properties of human self-organizing systems that are continually recreated and re-experienced during cognitive and perceptual activity. This perspective helps restore image schemas to their rightful status as "experiential gestalts" that are psychologically real, not because they are part of the mind, but because they are meaningful, stable states of embodied experience. Gibbs (2010) expresses strong disapproval regarding this statement, deeming it unreasonable and inappropriate to characterize image-schematic meaning construction as activation within some network that is abstracted away from experience, laying substantial emphasis on the fact that our understanding comes into being owing to basic sensorimotor knowledge and experience. He proposes that image-schematic reasoning is always being recreated on-the-fly by the body as people continue to engage in sensorimotor behaviors.

\section{Data and Research Methods}

The subjects of this research are football-transfer-related news which feature latest transfer information about football players (mostly), coaches, football clubs (ownership transfer), discussing the prospective/completed transfer events, generally loaded with the FPCTN writers' epistemic and evaluative attitudes. The reasons why we chose FPCTN discourse as our research targets are that football is attracting enormous attention from all walks of life in China and around the globe as well, and that the economic and business value in this sport is enormous and influential.

The data in this research had been collected from authoritative and professional sports news websites as listed in Table 1, dated from April 2015 to March 2016. 
Table 1. Chinese data source

\begin{tabular}{cc}
\hline Data Source & number \\
\hline http://sports.sina.com.cn & 12 \\
http://sports.qq.com & 12 \\
http://sports.sohu.com & 12
\end{tabular}

There were altogether thirty six pieces of football transfer news from the most popular Chinese websites, among which, twenty seven discourses were concerned with football player transfer, three with coach transfer and five with club ownership transfer, and one with both player and coach transfer (see Appendix).

The analyses were conducted to apply the image-schematic cognition-based approach to the analysis of FPCTNs. The research methods consisted of both qualitative and quantitative approaches. The qualitative method played a dominant role, and the quantitative method was applied to support and illuminate the qualitative method and cognitive generation. News reports were analyzed for presence of image schemas. An expression was evaluated as carrying image schemas based on common recurrent bodily experiences and various structures in orientations and relations. Afterwards, these image schemas were categorized into different sorts and effects of different image schemas achieved thereby were individually examined. Then the authors applied quantitative analysis to identify the approximate proportion of image schemas to detect the preferences of Chinese FPCTN writers in their writing processes, which enabled the authors to discover the frequencies and preferences of the FPCTN writers' cognitive schemas and their impacts on news readers.

\section{Schematic Analyses of Chinese FPCTNs}

To interpret the general cognitive mechanisms of discourse consumers, and have a better understanding of how FPCTN writers build up the informative "mansion" with the raw materials of information, their personal embodied life experience and honed skills, the authors choose the five most significantly applied schemas from data to illustrate their construals and default linguistic patterns in Chinese FPCTNs. The five schemas can be further classified into three groups: one is formulaic schemas, and the other two are metaphysical and metaphysicalized schemas.

\subsection{Formulaic Image Schema}

Formulaic image schema usually refers to explicit references to a concrete evidence or object on which it is based, for example, Table, Container, Road, Rice and their objective images and so on, which are often expressed through formulaic expressions based on communicators' universal and common experience with less cultural variations. In the data, containment and PATH images are two evident schemas widely applied in FPCTNS. According to Dewell (2005), CONTAINMENT defines a location, and PATH can then be structured to go into, out of or through that basic location. This remark establishes connections between CONTAINMENT Schema and PATH Schema, which is conducive to our logical analysis of FPCTNs.

\subsubsection{CONTAINER Schema}

CONTAINER/CONTAINMENT, as a typical formulaic image schema, has been a convincing instance in existing image-schema literature in sports news due to the pervasiveness of containment and boundedness in our daily activities. It characterizes a universally important semantic concept that is remarkably similar across languages and develops from early time span across languages. It is grounded in a wide range of common basic experiences which might be attributed to the high frequency use of containers in pragmatics.

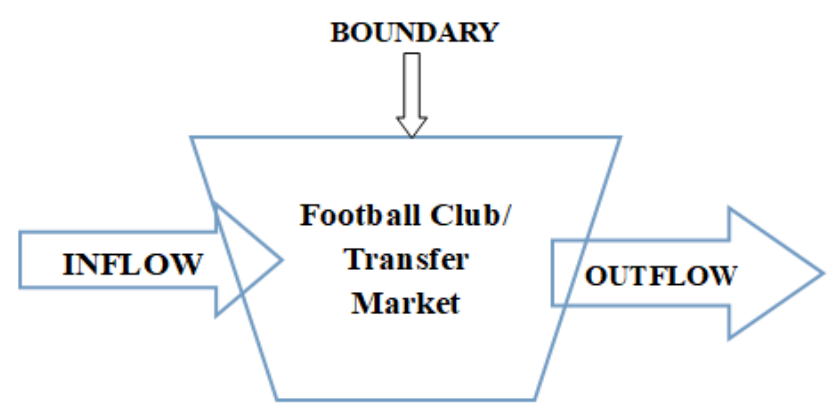

Figure 1. CONTAINER Schema

In daily life, we experience a broad range of physical containment during our interaction with the outside world. When we wake up in the morning, we climb out of our pajamas and into clothes proper for school or work, move from the bedroom to the bathroom where we pick up a tube of toothpaste, and squeeze out some onto the toothbrush, then put the 
toothbrush into our mouth and brush our teeth. In this case, we come across numerous containers on a daily basis, so frequently that we hardly notice them. When it comes to language expression and understanding of abstract information and relationships among different things, we tend to establish certain temporary linkages or mappings based on our bodily experience of physical CONTAINMENT (see Figure 1) to facilitate our communication.

Example 1

接受现代快报记者采访时, 孙可本人表达了希望留在舜天(stay in Shuntian)的愿望。(Text 1)

When taking the interview with Modern Express, Sun Ke expressed his wish to stay in Shuntian.

\section{Example 2}

但是到了其他球队, 一切又都需要重新开始, 新的球队, 新的管理层, 新的队友, 你是否能很快地融入进去 (fit in), 这些因素都要想好。(Text 1)

However, in the case of getting transferred to another team, everything will start all over again. With the new squad, new management, new teammates, you need to think in advance about whether you could fit in quickly.

Both Example 1 and 2 similarly express that football clubs are conceptualized as giant CONTAINERs that accommodate plenty of substances, i.e. football players who place themselves in different football clubs where their behaviors will be restricted by relevant rules and regulations just like the bounding surfaces of a container (the football club). Players' acts must conform to the requirements of the club to meet with the squad at precisely the scheduled time, to attend training and pre-match warm-ups on time, to refrain from staying out late and drinking alcohol the night before the upcoming match, and from involving any transfer negotiations with other clubs without the parent club's consent. The club is utterly conceptualized as CONTAINER which has its boundaries, spaces, demanding appropriate behaviors and allowing only legitimate entry and exit.

The container-related expressions attributed to relatively metaphysical containers enable news readers to recreate an embodied construal of transfer events as taking place within a specific containing environment where freedom of movement is constrained. If the employment contract is still effective, the player will be obliged to act accordingly with the regulations. Once the contract is expired or enters into a certain stage where negotiations are given green light, the player will have the freedom to determine whether he would like to remain part of the original club or choose another club to work in. Example 2 interprets that the player has to build social connections from scratch. Consequently, he has to do as the Romans do to break some new ground, so as to be accepted and included into the new community (another CONTAINER).

Examples 1-2 are also grounded upon the constural of football clubs as CONTAINERs and embodied simulation of placing oneself within the CONTAINERs. At the moment, a state of emergency has occurred; the giant CONTAINER suffers accidental physical contacts with outside forces/objects, which results in a loss of substances (capital or talents) or a leaking hole that requires refills or immediate repair treatments. In this event, additional materials (extra funding or new talents) will be called for to fill the vacuum caused by the accident. An alternative scenario (Example 2) is that the guardians (top executives of football clubs) decide to voluntarily change the content in the CONTAINERs; as a result, they choose to pour out or pick out some of the elements that they would like to discard and make room for fresh supplements.

\section{Example 3}

任航由于仅剩一年工作合同, 早已是转会市场上的香饽饽, 这条大鱼能否流到冬窗市场 this big fish will flow into the winter transfer market)，舜天(Shuntian)能否最终问鼎足协杯冠军或有决定性作用。(Text 13)

Since Ren Hang has only one year left in his contract, he has already become hot property in the transfer market; whether Shuntian will win the FA Cup may have a decisive role in determining whether this big fish will flow into the winter transfer market.

"Market" in Example 3 automatically establishes connections with our buying and selling behaviors and experiences in our daily life, and readers will unconsciously recreate a simulation process of buying and selling in handling such a description. In this case, readers build an image-schematic (CONTAINMENT) understanding of the event in which the virtual footballer transfer market is conceptualized as a giant CONTAINER filled with players of different levels who are available for business transactions, who await prospective purchasers. Purchasers appear in these markets with various intentions, mainly looking for ideal commodities to cater for their needs. Businessmen are allowed to negotiate over the details, especially the prices, as long as they behave themselves, because this CONTAINER has its borderlines (transfer regulations and limitations) which constrain relevant commercial behaviors.

\subsubsection{PATH Schema}


Another typically applied schema is path- or road-related expressions. Our lives are filled with paths that connect up our spatial world (Johnson, 1987). Some of these paths/roads involve traversing a physical surface, such as the path from the workplace to the supermarket, while other paths/roads are only imaginary or pass through a spatial trajectory, bearing the mission of establishing connections, such as the path from the Earth to the Mars. All of these instances seem to be characterized by a single recurring image-schematic pattern with the following elements: a source, a starting/ending point, a place; a goal; and a sequence of intermediate locations linking up the source with the goal, and the beginning with ending. Paths/roads are thus routes for movement from location to location. In light of its constitution, such typical recurrent image-schematic patterns are hence named SOURCE-PATH-GOAL Schema, or succinctly PATH Schema (see Figure 2).

Scenario 1: The smoothness of transfer negotiation

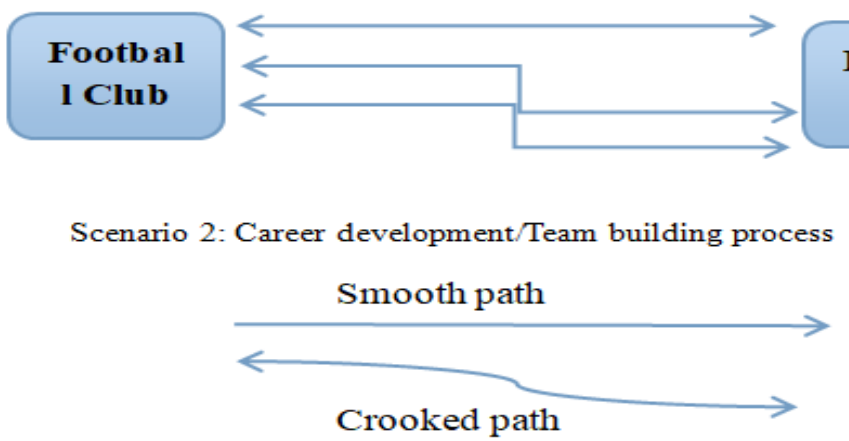

Figure 2. PATH Schema

Commercial transaction of players is common for professional football clubs, because whether a player or a coach has a successful career in a certain club depends on lots of factors. If a player or a coach is incapable of giving stunning performance equivalent to the price the club paid to bring him in for a long time, the club will lose confidence and patience in him out of the pressure from the fans and the board of directors, as poor performance of the team is likely to result in the decrease of the club's share value, thus causing substantial financial losses. In that event, the player/coach will be dismissed or put into the market for sale, and meanwhile, the club will target prospective replacement. On the other hand, the player sometimes will have the upper hand and take the initiative to submit a transfer event and seek an alternative path; possible causes may include dissatisfaction with the remuneration package, the coach's tactic planning or the legitimate status in the squad. Hence, the club will be obliged to adopt forceful measures to keep the player or to start negotiations with interested purchasers. The negotiation process will be arduous on account of the interest of different stakeholders, and hence can be conceptualized as PATHs leading to various directions and destinations.

\section{Example 4}

孙可告诉记者: “没有人想带着老婆孩子去(go to)陌生的地方闯荡(venture in a unfamiliar place)。”(Text 1)

Sun Ke told the reporter: "nobody would want to venture in an unfamiliar place with his wife and child."

\section{Example 5}

黄健翔说: “对于孙可来说, 转会是一把双刃剑, 千万不要只看眼前, 应该更多地去考虑, 如果走去(walk to / transfer to)其他球队，方方面面的环境是否适合自己？”(Text 1)

(Football commentator) Huang Jianxiang said: transfer is a double-edge sword for Sun Ke. He must not simply think about the present moment, but should focus more thoughts on whether all sorts of conditions will be suitable for him if he joins another team.

Football player Sun Ke, in Example 4, told the reporter that he is reluctant to bring his wife and child to "go to / transfer" to a strange place. Meanwhile, in Example 5, Football commentator Huang Jianxiang comments on Sun Ke' leaving as: "walk to / transfer" is a double-edged sword for Sun Ke, and he should not simply think about the present moment, but should focus more thoughts on whether all sorts of conditions will be suitable for him if he joins another team.

In general, two sorts of simulated PATH can be identified in FPCTNs: player and coach's career development routes in a club, and the smoothness of the ongoing negotiation process. These are dynamic processes that typically involve an initial state and final state, with numerous intermediate actions in between. Gibbs (2003) has always advocated an embodied view of linguistic meaning and refused to conceive of meaning and human cognition in terms of abstract and disembodied symbols. He seeks to acknowledge the importance of embodiment in accounting for a significant part of language use and meaning. We move from place to place on a daily basis and have established familiar mobile patterns (PATH Schema) during our embodied activities. Taking the perspective of Sun Ke, we could imagine that he has no 
alternative but to leave the team, bringing his wife and child to a strange place, and laying all sorts of foundations all over again, which would be overwhelmingly frustrating and challenging. Our brains continuously engage in such imaginative construals of linguistic meaning, and we experience emotions as part of our simulation processes on PATH and its related behaviors, going and walking.

News readers will automatically engage in these simulation processes when facing such cognitive abstract reasoning tasks, and they will experience the emotions and psychological status of the subject as well. As we can see, both CONTAINER and PATH Schemas are recurring universal patterns in our experience which play a crucial role in our making sense of holder and the world routes, often with formulaic and concrete expressions and less interpretative variations.

\subsection{Metaphysicalized FACE Image Schemas}

It should be noted that in Chinese, there are many expressions which originally are the concrete objects applied in metaphysical states. FACE, unlike formulaic and conceptualized images CONTAINER and PATH, as a concrete object of human beings, is often used in the forms of verbs, adjectives or adverbs to indicate a metaphsicalized state or action. As a body schema can be considered the collection of processes that registers the posture of one's body parts in space, the Chinese metaphysicalized the body parts into abstract ones, especially when referring to moving actions. The schema is updated in the course of body movement and used primarily for spatial organization of action, which takes place automatically, independent of our consciousness. As Yu (2009) proposes that the Chinese people use a larger number of body parts for the conceptualization of emotions than the English people do. The feature of the language is directly related to the cultural models of emotions inherited from Chinese medicine, which focuses on the direct physiological effects of emotions on the body's organs. Over the course of a lifetime, body schemas provide continuous support for the regular functioning of various body- and feeling-related image schemas. Therefore, it can be deduced that image-schematic meaning construction and interpretation constantly seek to employ sensorimotor processes which are critical to the Chinese people's understanding of themselves, other people and their physical and cultural surroundings. For instance, face is an important concrete part of the Chinese body which relates to their esteem, pride and core value.

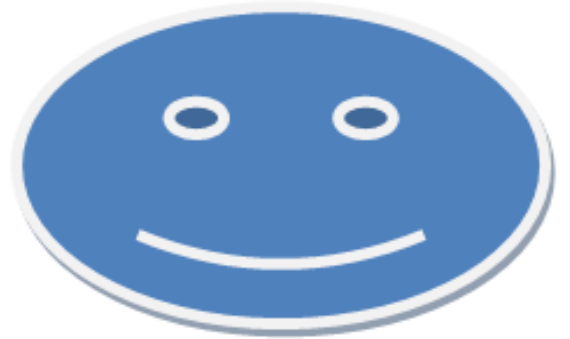

Figure 3 FACE Schema

As Yang and Zhen (2017) point out that face, as a socially and culturally attributed aspect of self and community, was temporarily on loan for the duration of the interaction in accordance with the line or lines that the participants had adopted. In Chinese society, face is a very complicated concept and it involves reciprocal social attribution. Nevertheless, FACE phenomenon and the Chinese people's cognition of it are more complicated and involve more linguistic recognitions and applications in reality (see Figure 3). In many cases, face is not a concrete face of a person or surface of an object anymore, but a metaphysicalized phenomenon. Here are some examples:

\section{Example 6}

对此, 舜天俱乐部高层表示: “从理论上来说, 这个可能性确实存在, 但作为俱乐部来说, 不愿也不想看到这 样的局面(noun face: situation)。(Text 1)

Hence, the top management of Shuntian Club indicates that: "theoretically, this possibility might exist, but as for the club, (we) don't want to see such a situation."

\section{Example 7}

不单单是自身资历和能力, 还有一件事别忘了, 他还是中国现在足球圈中, 唯一和习大大正面( adverb face: face to face) 对话和握手的足球人。(Text 14)

Besides self-qualification and capability, there is one thing should not be ignored. He is, in the circle of China' football, the only one who had the chance to meet Chairman Xi face to face and shake hands with him. 


\section{Example 8}

俱乐部高层也坦言: “职业足球就是这样, 竞争每时每刻都存在, 不仅仅是顾超, 所有人都需要通过自己的努 力去赢得主力位置, 再加上新赛季我们将面临(verb face: confront with)多线作战, 无论从球队整体实力考虑, 还是从板登深度考虑, 都需要尽可能地去补充有竞争力的球员。唯有如此, 才能在新赛季尽可能地打好所有 比赛。”(Text 18)

The club's top executives also said frankly: "Professional football is such that competition exists all the time. Not only Guchao, all players need to fight for the starting line-ups through their own efforts. Coupled with the fact that in the new season we will face battles on multiple fronts, no matter out of considerations for the team's overall strengths or the depths of bench players, we need to supplement as many competitive players as possible. Only in this way will we play well in all competitions in the new season."

In Chinese culture, life is filled with all kinds of physical objects which present the Chinese people with a wealth of faces, namely, a face can refer to the human's face, top layer or the outside of something, as in the earth's (sur)face, the object faces, the face of politics; it can also indicate a flat area on which you can work, such as the top of a table, desk or kitchen cupboard; with the passage of time, despite its probable origin from human perception of physical objects or appearance of a person, the notion of (sur)face has extended semantically and obtained degrees of abstraction, and thus can be interpreted as something that can be easily seen rather than what is hidden or not explicitly noticeable, with regard to collocation with abstract concepts such as the (sur)face of a situation. In addition, (sur)face can be used as a noun "situation", an adverb "face-to-face" or a verb "confront with" as in the above-mentioned Examples 6,7,8. The claim that image schemas underlie linguistic meaning implies that we should carry out simulation processes in order to recreate an embodied model of what is meant. Encounter with the word (sur)face will immediately summon all the relevant information at our disposal and personal experiences to our mind. Making an instant connection and creating embodied simulations between the word "(sur)face" and a series of past experiences help form a vivid picture of the scene and enable us to comprehend the underlying meaning of "(sur)face" without having to actually perform such strings of actions.

The experientially basic, value-laden structure of our grasp of both concrete and abstract entities is one of the most pervasive image-schematic structures in our understanding (Johnson, 1987:123). Abstract entities of many sorts are adequately covered due to the extension of this image schema which initially springs from our experience of concrete and physical entities.

\subsection{Metaphysical Image Schema}

Metaphysical image schemas, on the other hand, should be noted as non-communicative discourse or mode, such as Air, Contexts, Degrees and their subjective images. Many actions, which need people's personal experience and audio visions to frame certain pictures or imaginations in their brain, also belong to this category, such as FOOD COOKING Schema.

\subsubsection{FOOD COOKING Schema}

Many instances in the data can be illustrated to demonstrate the influence image schemas may exert on the Chinese people's construal and understanding of events. Chinese sports news writers display a strong tendency to link the operation of football transfer news to a critical part of their daily life, such as cooking or food-making. This tendency demonstrates closely the Chinese unique food and its images, and the food-related culture (see Figure 4). 

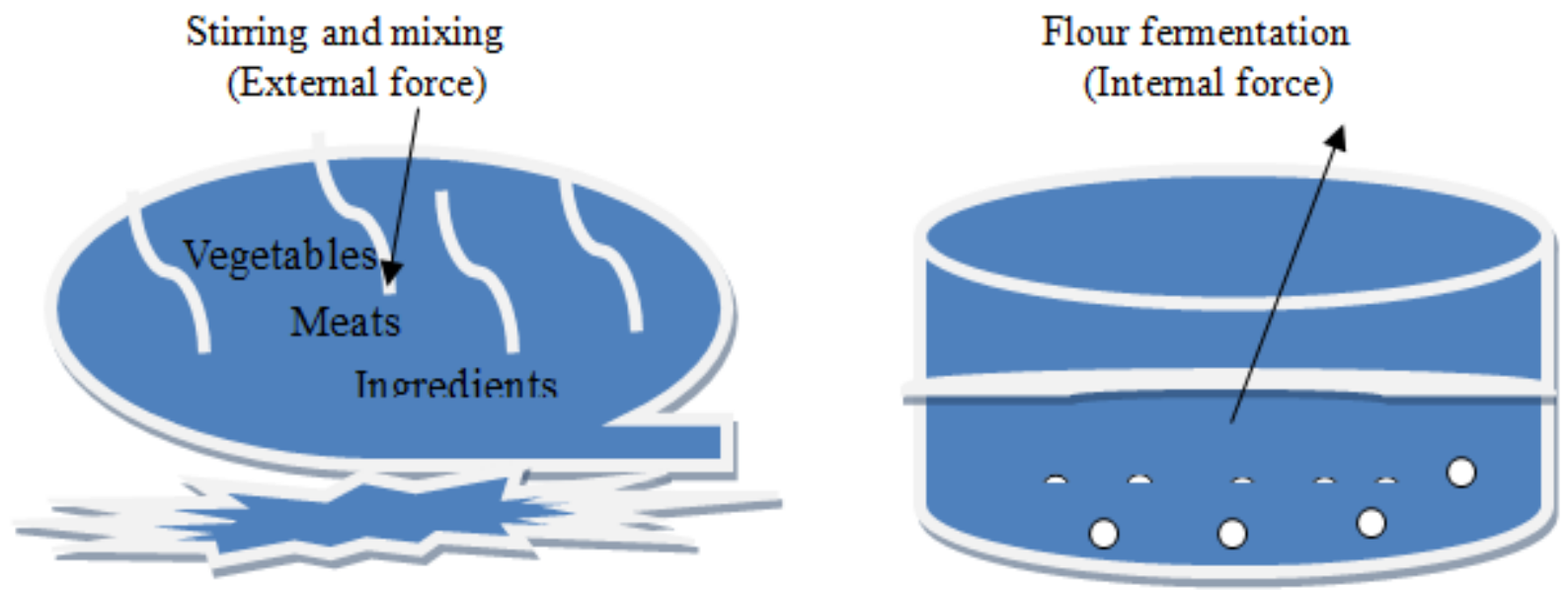

Figure 4. FOOD COOKING Schema

There are lots of Chinese vocabularies having force directions, such as “炒 chao (fry)”, “搅 jiao (mix)”, “打 da (beat)” that some an object or person must use external force to conduct the action, while “发酵 fajiao (ferment)”, “滋生 zisheng (breed)" and “蜕变 tuibian (decay)" that some an object must use internal force to extend itself and become bigger, stronger or worse. These words can denote, by default, the writers' intentions or states to exhibit some grammatical behaviors which project writers' subjectivity and cognition of the world.

\section{Example 9}

值得一提的是, 负责运作张琳艺的是上海某经纪公司, 该公司曾经运作过上海籍球员赴欧洲留洋, 而该公司 的股权结构与某媒体密切相关, 这也是张琳范转会一事被炒得沸沸扬扬(fry: hype up) 的主要原因。(Chinese text 4)

Notably, it is a Shanghai brokerage firm that presides over the transfer of Zhang Linpeng, the same company which managed the transfer of a Shanghainese player to an European club and whose ownership structure is intimately related to a media company. These are the reasons why the transfer of Zhang Linpeng has provoked (hyped up) a great deal of discussion.

\section{Example 10}

\section{关于切尔西“引进”张琳艺的一事近日持续发酵(ferment: further develop)。(Chinese text 4)}

The rumor regarding Chelsea's intention to bring in Zhang Linpeng has undergone continuous fermentation the past few days.

“炒(chao) fry” in Example 9 refers to one of the most commonly cooking methods with outer force in China: frying food in oil or fat in a hot pot with one's hand and spatula. In such a cooking context, it is highly likely that we would automatically establish a connection between the transfer event with the ordinary cooking scene in our daily life, recalling all the specific procedures involved in the action of frying: starting the fire, pouring in some oil or fat, heating up the pan, dropping in the raw material, adding some sauces and condiments to improve the flavor, covering the pot, and ultimately waiting for the appropriate time to serve the dish. We simulate these series of actions in our mind without the necessity of actually performing them, as part of our imaginative understanding of this linguistic expression. We project this sort of doing/force giving orientation onto other objects to help ourselves make sense of the world around us. Semantically speaking, meaning extension surrounding the concept “炒 chao (fry)” is everywhere, such as 炒股 chaogu (to speculate in the stock market), 炒楼 chaolou (to speculate in the property market). Apparently, “炒 chao (fry)” refers to the practice of engaging in risky financial transactions in an attempt or with a certain outer force for profits from fluctuations in the market value of tradable goods.

Likewise, the same explanation can be elicited in the case of “发酵 fajiao (ferment)" in Example 10. Fermentation is a metabolic process that converts sugar to acids, gases or alcohol, developing itself internally. It occurs in yeast and bacteria, and also in oxygen-starved muscle cells, as in the case of lactic acid fermentation. Fermentation is also employed more broadly to denote the bulk growth of microorganisms on a growth medium, often with the aim of producing a specific chemical product with internal force. It is one of the earliest biochemical reactions that human beings have created and applied to industries, which is closely related to our everyday life, such as the food-making industry, bio-tech industry, and chemical industry. It makes perfect sense that even common people have no strangeness to such a concept and its biochemical process with things that happen around us. In Chinese, “发酵 fajiao (ferment)” 
can also refer to the situation in which things undergo some sort of change or development due to the effects of internal forces with the existing substances. Hence, in Example 10, the word “发酵 fajiao (ferment)" implies the simulation of an item (the transfer rumor) that is experiencing some changes in the duration with various internal forces, like official statements, comments of players and famous sports commentators are all involved. Hence, as every single minute passes by, some transformations will be completed within the item itself, and the item will probably take on a new growing look; in the event of football transfer news, some new elements will appeared or generate to different stories with respect to the same event.

\subsubsection{SCALE Schema}

Scale in Chinese is frequently expressed with vague and abstract expressions on range, scope and degree. SCALE Schema refers to a dimension which crosscuts many different types of perceptual and non-perceptual experiences. Our world is experienced partly in terms of more, less, and the same. We can have more, less, or the same number of objects, amount of substances, degree of force, or intensity of sensation (see Figure 5). This "more" or "less" aspect of human experience is the basis of the SCALE Schema (Johnson, 1987:122).

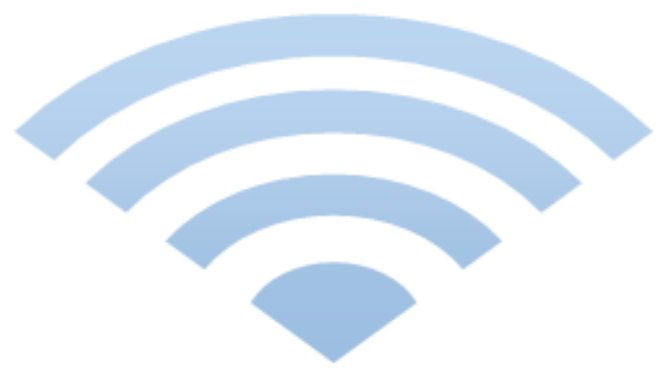

Figure 5. SCALE Schema

SCALE is a metaphysical parameter of degree that is employed to describe both physical objects and abstract entities involved in specific events. This type of measurement tool is rather ubiquitous in human experience; it is fundamental to both the quantitative and qualitative dimensions of our experience. As far as the quantitative dimension is concerned, our physical world is experienced as consisting of dissimilar objects that we can categorize in numerous ways and substances we can increase and decrease. As regards the qualitative dimension, physical objects and events are generally experienced as possessing a certain degree of intensity.

\section{Example 11}

“此前有很多球员, 一味追求去更好的球队(better team), 拿更高的工资(higher salary), 但最后结果却是职业 生涯都荒废了, 得不偿失啊。”(Text 1)

"Previously, many players simply went after better teams and higher salaries, but ended with completely wasted careers; the loss outweighs the gain."

\section{Example 12}

斯托伊科维奇把这次保级任务称为“不堪回首的艰苦考验”, 因为难度比他之前想象的大太多(more difficulties than he imagined)。(Text 2)

Stojkovic refers to this avoiding-relegation mission as "arduous ordeal that he cannot bear to think of", because the difficulty was much greater than he had imagined.

It is obvious that the phenomenon of SCALE schematic constructions are "rampant" in Chinese reports, and that "more, higher and better" in Examples 11 and 12 which involve comparative-degree grammatical devices indicating a comparison/change of the status of quantity/quality. Noticeably, not all the targets surrounded by modifiers are physical objects, and these modifying devices are frequently employed in describing metaphysical degrees. Nonetheless, news readers are still open to build embodied simulations to figure out these expressions and feel at abstract levels.

\section{Example 13}

在保级最危险(most dangerous situation for avoiding relegation) 的时候, 这家公司甚至做好了从中甲接过球队的 准备，显然对于投资天津足球有着不小的 (not small) 热情。(Text 3)

Even in the most dangerous situation of avoiding relegation, this company prepared itself to take over a China League team; it obviously has great enthusiasm in investing Tianjin Football. 


\section{Example 14}

不过, 据知情人士透露, 切尔西方面的报价远远没达到(far below)张琳艺之前与俱乐部达成的“留洋触动条款 的最低报价(the lowest quotation)”。(Text 4)

However, according to informed sources, the offer from Chelsea is far below the lowest quotation that was agreed upon between Zhang Linpeng and the club to trigger an overseas transfer.

\section{Example 15}

埃尔克森坦言: “我总是想赢, 你在国外踢球, 没有什么比(nothing is better than)赢得冠军更好的了, 所以这 对于一个球员来说是最大的动力(the greatest motivation)。”(Text 5)

Elkeson admits honestly: "I always want to win, and there's nothing better than winning the champion, which is the greatest motivation for a player."

Examples 13-15 present different scale expressions rather than comparatives in Examples 11-12. These examples are picked up because all of them contain superlative-degree devices, signifying the extreme levels of concepts. They are pervasive in expressing the pole value of adjectives: "the most dangerous situation" in Example 13, and "the lowest quotation" in Example 14, in describing a motivational level "the greatest motivation" in Example 15. People often feel inspired to perform actions that may prompt preferable results. However, in Chinese, SCALE schemas are often abstract and implicit in the degree description. "Not small", "far below" and "nothing is better than" in Examples 13-15 all present metaphysical images for news readers to digest the degrees with different answers: " $50 \%$ ? 70 ? or $90 \%$ ?......" which leaves readers great imagination space, based on their own experience and sports knowledge.

\section{Example 16}

\section{财大气粗的后者甚至做出了年薪翻番(double annual salaries)的承诺。(Text 26)}

The latter with deep pockets even made the promise of doubling annual salaries.

Example 16 shows another frequently adopted tool to reveal change of quantitative status. It's interesting that words like double, treble seem to have underlying scalar schematic structures to offer them inherent scalar meanings. It is obvious that the instances enumerated generally have something to do with the concept of amount/number. Put another way, the SCALE Schema is normally characterized by both its cumulative and decrescent features, though most of the cases above are cumulative-prone.

As we can see, this schema is employed to define not only concrete entities such as money, but also abstract entities such as the competitiveness of a team, the complexity of a situation, the degree of commitment to one's profession. One thing that should be noted is that when SCALE Schema is involved in concrete entities the focus generally falls on the quantitative dimension, and when SCALE Schema is involved in abstract entities, we are in general talking about the qualitative dimension.

\section{Chinese Preferences of Image Schema Application in FPCTNs}

While qualitative analysis shows how we human beings make sense of our physical surroundings and metaphysical information in different cognitive tasks with the aid of image schemas and that image schemas assume significant roles in our life and communication, quantitative analysis will unfold an entirely different landscape which clearly indicates writers' general linguistic preferences and the application proportion of various linguistic elements that constitute the main body of FPCTNs, which helps to generate the Chinese FPCTN writers' cognitive frame and its impacts on FPCTN readers. Within the database, the calculated results demonstrate the applications frequency of image schemas in Chinese FPCTNs as:

Table 2. Numbers of image schemas in Chinese FPCTNs

\begin{tabular}{llll}
\hline Contents & Image schema & \multicolumn{2}{l}{ Numbers in Chinese FPCTN } \\
& & 541 & $100 \%$ \\
Metaphysical (242) & FOOD COOKING & 63 & $12 \%$ \\
& SCALE & $\mathbf{1 7 9}$ & $\mathbf{3 3 \%}$ \\
Formulaic (223) & CONTAINER & 114 & $21 \%$ \\
& PATH & 109 & $20 \%$ \\
Metaphysicalized (76) & FACE & 76 & $14 \%$ \\
\hline
\end{tabular}

The results on image schema in Table 2 demonstrate a tendency from high-level to low-level: 

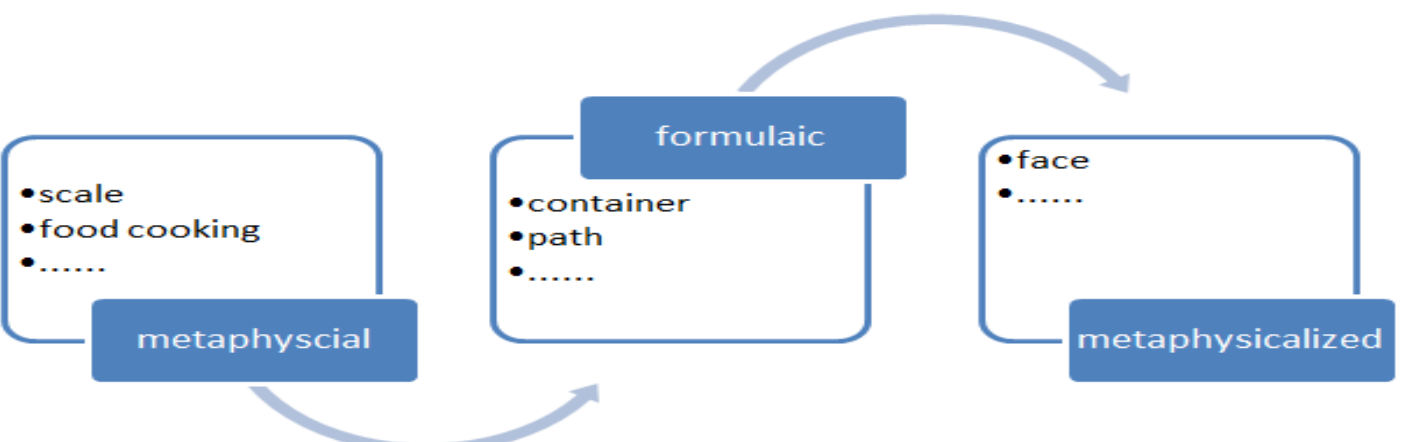

Figure 6. Preferences of Image schemas in Chinese FPCTNs

Specifically, Chinese people's Schematic preference (see Figure 6) is SCALE $>$ CONTAINER $>$ PATH $>$ FACE $>$ FOOD COOKING. The pattern demonstrates that Chinese people's cognitive frame is chiefly built on their metaphysical images and knowledge. The vase use of SCALE in discourse shows the constantly-changing scalar status in both qualitative and quantitative dimensions. The world of professional football is dynamic, and situations run in a state of flux: the prices of players are always changing in accordance with their performance on the pitch, and the competitive shape of football teams that varies from time to time. In terms of other image schemas, CONTAINER Schemas are more frequently seen in reports, showing football writers tend to conceptualize various scenarios in their area of expertise (football transfer reporting) in terms of CONTAINER structures and favor the use of this schema in encoding the messages they want to send to readers. The large number of PATH schema is conceivable since FPCTNs usually touch upon the driving factors behind specific transfer events or rumors, and the devious paths the subjects of the news have been experiencing may motivate the transfer or introduction of players to justify the clubs' past misdoings or help clubs to reach to next possible successful destinations. As for FACE and FOOD COOKING schemas, people's cognitive processes and interpretations are embedded with and impacted by the Chinese culture. Such a schematic preference reflects a proposed model of language and linguistic organization which in turn project what is known about in people's mind.

Although cognitive or image schemas of different linguistic expressions, either semantic or pragmatic, are available in various topologies, a close examination into the cognitive behavior and structural patterns of each construal in sport discourse reveals dynamic and different construal for the default ones. Concrete image schemas, like CONTAINER and PATH, seem to be universal default cases in the schematic configurative expressions across cultures, while in the Chinese abstract and metaphysical image schemas, FACE, FOOD COOKING and SCALE are the norms regarding cognitive processes. This can be seen in the fact that most concrete construal in configuration expressions is compositional in its formulation, while that in Chinese metaphysical expressions are non-compositional and their subjectivity are inherent to the contexts and their (implied) interpretations. The schematic analysis so far presented offers an interesting account of the nominative image schemas for both metaphysical and formulaic expressions, and the metaphysicalized process of formulaic expressions. The overt metaphysicalized role is in the discourse contexts, and need to be assigned grammatical role in the conceptual structure on lexical or sentence levels. Furthermore, the current study can arguably shed new light on the study of image schemas itself. The semantic compositional process of image schematic expressions in Chinese, in fact, represents the synchronic process of metaphysical and formulaic patterns which become default ones to construe both discourse writers and readers compositional process to the sentence and discourse levels.

\section{Conclusion}

Within cognitive linguistics, the study of cultural models has gone hand in hand with the study of the conceptual and experiential basis of linguistic categories (e.g. Geeraerts \& Cuyckens, 2007). Kövecses (2009:4) emphasizes that "the relationship between culture and language can be dealt with if we assume that both culture and language are about making meaning". Meaning making, therefore, should be considered as a broad concept that pertains to cognitive, linguistic and social abilities. On the cognitive process of sports news writers and readers, we argue that their discursive changes within the process of cognition have generally been reasonably both concrete and metaphysical. The sports news writers, who might represent the sports clubs and institutions, transformed their conceptions and perceptions into public readers. They carefully and strategically integrated the concept and sensibility of players' "trading" into the discourses and players were in effect to bring the club to "rise in rank" and financially payoff. Thus, the nature of language, the mind, and their relationship with sociophysical (embodied) experience in the interdisciplinary study of schematic images and constructions are organized in an individual's mind as a network, with both metaphysical and formulaic schemas at different levels of schematicity, presenting different process of cognitive entrenchment. 


\section{Acknowledgement}

The research is revised and completed with the assistance of Prof. Yves Tiberghien from Institute of Asian Research of University of British Columbia, Canada and MOE project for Chinese scholars overseas [2017]3059, to which we feel deep gratitude. This research has been supported by the MOE Project of Humanities and Social Sciences, Ministry of Education, China on "Empirical Cross-cultural Studies on Social Discourses and Their Cognitive Frames" (No. 14JJD740011), and by the MOE Project of the Center for Linguistics and Applied Linguistics, Guangdong University of Foreign Studies. We are also very grateful to the journal reviewers and editors for their comments for the revision of this paper. We are the persons who are solely responsible for all the remaining errors and shortcomings.

\section{References}

Aitchison, C. (Ed.). (2007). Sport and gendered identities. London: Routledge.

Carrington, B., \& McDonald, I. (Eds.). (2009). Marxism, cultural studies and sport. London: Routledge.

Damasio, A. (1999). The feeling of what happens: Body and emotion in the making of consciousness. New York: Harcourt Brace and Co.

Damasio, A. (2003). Looking for spinoza: Joy, sorrow, and the feeling brain. New York: Harcourt Brace and Co.

Dana, E. M., Erin, B., \& Anita, A. S. (2011). 'Characterizations of criminal athletes: A systematic examination of sports news depictions of race and crime', Journal of Broadcasting and Electronic Media, 55(4), 526-542. https://doi.org/10.1080/08838151.2011.620664

Dewell, R. (2005). 'Dynamic patterns of CONTAINMENT'. In B. Hampe (Ed.), From perception to meaning: Image schemas in cognitive linguistics (pp. 369-394). Berlin: Mouton de Gruyter. https://doi.org/10.1515/9783110197532.5.369

Foucault, M. (1972). The archaeology of knowledge. New York: Pantheon.

Frow, J. (2006). Genre. London: Routledge.

Gallagher, S., \& Cole, J. (1995). Body image and body schema in a deafferented subject. Journal of Mind \& Behavior, 16(4), 369-389.

Geeraerts, D., \& Cuyckens, H. (2007). Introducing cognitive linguistics. In D. Geeraerts, \& H. Cuyckens (Eds.), The oxford handbook of cognitive linguistics (pp. 3-21). Oxford/New York: Oxford University Press.

Gibbs, R. (2003). Embodied experience and linguistic meaning. Brain and Language, 84(1), 1-15. http://docshare02.docshare.tips/files/30482/304827824.pdf.

Gibbs, R. (2006). Embodiment and cognitive science. New York: Cambridge University Press.

Gibbs, R. (2010). Stability and variation in linguistic pragmatics. Pragmatics and Society, 1(1), 32-49. https://doi.org/10.1075/ps.1.1.03gib

Johnson, M. (1987). The Body in the mind: The bodily basis of meaning, imagination, and reason. Chicago: The University of Chicago Press. https://doi.org/10.7208/chicago/9780226471013.001.0001

Kövecses, Z. (2009). Metaphor and culture. In H. Grabes, A. Nünning, \& S. Baumbach (Eds.), Metaphors shaping culture and theory (pp. 3-16). Tübingen: Gunter Narr Verlag.

Lakoff, G. (1987). Women, fire, and dangerous things: What categories reveal about the mind. Chicago: The University of Chicago Press.

Lakoff, G. (1990). The invariance hypothesis: Is abstract reason based on image-schemas? Cognitive Linguistics, 1, 39-74. https://doi.org/10.1515/cogl.1990.1.1.39

Lakoff, G., \& Johnson, M. (1980). Metaphors we live by. Chicago: The University of Chicago Press.

Li, K., \& Li, S. K., (2010). The cognitive mechanism of NP anaphora construction in sports news text. Journal of Beijing University of Aeronautics and Astronautics (Social Sciences Edition), 23, 95-100.

Liu, L. X., \& Liu, D. M. (2005). Talking about metaphors in sports news texts and their functions. Journal of Vocational and Technical College, 15, 33-35.

McGannon, K. R. (2016). Critical discourse analysis in sport and exercise: What, why and how. In B. Smith, \& A. Sparkes (Eds.), International handbook of qualitative research in sport and exercise (pp. 230-242). London and New York: Routledge.

Schirato, T. (2013). Sports discourse. London, New Delhi, New York, Sydney: Bloomsbury. 
Shen, C. X. (2010). A study of Chinese-English code-switching in Chinese sports news reports. Cross-cultural Communication, 6(4), 165-175.

Smith, B., \& Sparkes, A. (Eds.) (2016). International handbook of qualitative research in sport and exercise. London and New York: Routledge.

Tomlinson, A. (Ed.). (2007). The sports studies reader. London: Routledge.

van Dijk, T. A. (1997). Discourse as structure and process. London: Sage Publications Ltd..

Wang, Y. (2013). Discourse analysis on sports news--A SFG approach. Shanxi: Shanxi Normal University.

Yang, W. W., \& Zhen, K. Y. (2017). 'Being direct or indirect?' --- Politeness, facework and rapport construction in Chinese interpersonal business requests. English Literature and Language Review, 3(6), 58-70. http://www.arpgweb.com/pdf-files/ellr3(6)58-70.pdf.

Yoshiaki, S., \& Yasuo, A. (2000). Automatic classification of TV sports news video by multiple subspace method. Systems and Computers in Japan, 31(6), 90-98. https://doi.org/10.1002/(SICI)1520-684X(200006)31:6<90::AID-SCJ9>3.0.CO;2-5.

Yu, N. (2009). From body to meaning in culture: Papers on cognitive semantic studies of Chinese. Amsterdam \& Philadelphia: John Benjamins. https://doi.org/10.1075/z.149

\section{Appendix}

1. 续约陷僵局舜天卖孙可? 二次转会前必须有说法

http://sports.sina.com.cn/j/2015-05-12/08367604746.shtml

2. 富力洋帅点名欲清洗 3 外援 盼换血下季带队进亚冠

http://sports.sina.com.cn/china/j/2015-10-29/doc-ifxkhcfn4163770.shtml

3. 曝天津泰达正商谈转让 某车辆上市公司或接手

http://sports.sina.com.cn/china/j/2015-11-02/doc-ifxkhcfn4264802.shtml

4. 揭秘张琳范留洋幕后 支持梦想拒绝出口转内销

http://sports.sina.com.cn/j/2015-08-30/12577689763.shtml

5. 埃神解释为何未离恒大 点 3 中国球员可立足欧洲

http://sports.sina.com.cn/china/j/2015-11-01/doc-ifxkhcfk7502488.shtml

6. 卡希尔否认回澳超暗示将续约 忠诚是他足球信仰

http://sports.sina.com.cn/china/j/2015-10-12/doc-ifxirmpz8265588.shtml

7. 鲁媒访库卡谈去留:如下课能理解 和管理层没友谊

(http://sports.sina.com.cn/china/j/2015-10-06/doc-ifximrxn8225030.shtml

8. 鲁媒:库卡对鲁能改造不成功 找不到他留任理由

http://sports.sina.com.cn/china/j/2015-10-03/doc-ifximrxn8182159.shtml

9. 曝张琳芒去皇马出场等问题还没定 等刘永灼谈

http://sports.sina.com.cn/china/j/2015-09-23/doc-ifxhzevf0970037.shtml

10. 重磅! 粤媒曝申花挖角郜林 荣吴无限接近离队

http://sports.sina.com.cn/china/j/2015-11-28/doc-ifxmazmy2207578.shtml

11. 鲁能绯闻新帅解约金超千万 经纪人:未收到报价

http://sports.sina.com.cn/china/j/2015-11-28/doc-ifxmaznc5746246.shtml

12. 建业再寻枪欲找登巴巴式前锋 被弃锋将重回母

http://sports.sina.com.cn/china/j/2015-11-27/doc-ifxmazmz8907035.shtml

13. 上港锁定人和悍将接班孙祥 动用人情补强防线

http://sports.qq.com/a/20151126/024621.htm

14. 神速！贵州抢签孙继海韩鹏汪强 王宝山任主帅 
http://sports.qq.com/a/20151113/010740.htm

15. 鲁能大调整! 三将确定离开 吴兴涵新赛季留队 http://sports.qq.com/a/20151128/023683.htm

16. 意媒曝鲁能欲引进卡卡 梅内塞斯亲自出面劝降 http://sports.qq.com/a/20160101/011122.htm

17. 张远加盟华夏只待官宣 离开富力只想离家近些 http://sports.qq.com/a/20151231/046259.htm 18. 邓小飞确认签约重庆 顾超破中超门将转会纪录 http://sports.qq.com/a/20160101/010487.htm 19. 力帆四将告别迎来三新人 传正在接触鲁能后卫 http://sports.qq.com/a/20160102/009584.htm 20. 曝人和中场核心或重返德甲 因球队降级心寒? http://sports.qq.com/a/20151228/047570.htm 21.3 次迁徙 16 个队名 ! 人和重商轻义恐最伤球迷心 http://sports.qq.com/a/20151229/013445.htm 22. 媒体批俱乐部转让迁移投机: 最典型贵州人和 http://sports.qq.com/a/20151230/015836.htm 23. 天津 32 岁铁卫盼落叶归根 想去泰达权健都不易 http://sports.qq.com/a/20151228/015805.htm 24. 京媒：国安卖股份换活法? 中超转会费恐成前 5 http://sports.qq.com/a/20151230/051581.htm 25. 曝恒大开高薪追姜至鹏 球员本人有信心竞争主力 http://sports.sohu.com/20160219/n437827922.shtml 26. 曝恒大皇马商谈达尼洛转会 巴西边卫今夏加盟? http://sports.sohu.com/20160214/n437326113.shtml 27. 弗兰: 遗憾马丁内斯赴恒大 中超豪购实则毁球星 http://sports.sohu.com/20160208/n437120864.shtml 28.3 亿砸大牌有盈余! 恒大正谈多家新赞助价格飙升 http://sports.sohu.com/20160204/n436869515.shtml 29. 曝上港 1700 万欧购埃神 将创中超球员转会费纪录 http://sports.sohu.com/20160120/n435144032.shtml 30. 上港正式报价恒大求购荣吴 转会费或超 6000 万元 http://sports.sohu.com/20151225/n432610072.shtml 31. 国安压哨换人克莱伯或将走人 亚外同样可能更换 http://sports.sohu.com/20160226/n438545938.shtml 32. 曝张呈栋告知高层冬季离队 或追随曼帅赴申花? http://sports.sohu.com/20160120/n435134722.shtml 33. 罗宁: 有人 1 亿挖国安球员 拉尔夫是升级版马季奇 http://sports.sohu.com/20160119/n435098720.shtml 34. 国安已同意出让 50\%股权 乐视先行支付部分款项 http://sports.sohu.com/20160116/n434716037.shtml 35. 曝力帆引援瞄准国安边卫 赵和靖: 没有官方接触 
http://sports.sohu.com/20151228/n432751798.shtml

36. 苏宁高层：第一身价物有所值 绝不会无底线抬价

http://sports.sohu.com/20160127/n436090795.shtml

\section{Copyrights}

Copyright for this article is retained by the author(s), with first publication rights granted to the journal.

This is an open-access article distributed under the terms and conditions of the Creative Commons Attribution license which permits unrestricted use, distribution, and reproduction in any medium, provided the original work is properly cited. 